\title{
PSYCHOMETRICS, RHETORIC, NARRATIVE IN MEDIA PSYCHOLINGUISTICS
}

\author{
Zinoviia Karpenko \\ https://orcid.org/0000-0002-0747-2591 \\ karpenkozs@ukr.net \\ Vasyl Stefanyk Pre-Carpathian National University, Ukraine
}

Received July 17, 2020; Revised August 29, 2020; Accepted September 12, 2020

\begin{abstract}
The paper is focused on the critical exploration of an experiment held in the Ukrainian media environment. The results of the experiment are reflected in the book Freedom of Speech Against Fear and Humiliation published by Savik Shuster (2018), the Ukrainian political journalist and the Freedom of Speech TV talk show host. The study aims to define factors and predictors of the Ukrainian audience's social behavior. In this regard, narrative, conversational, and intent analyses of his talk show participants' conflict interaction described in the book, were applied. These tools made it possible to explicate his narratives' main topics, their prominence, role positions, archetypal patterns of the participant, and host's behavior. The narrative structure of "negative" scenarios of the talk show described in the book enabled defining the host as the encourager of the speakers' conflict behavior, high tension of their discourse that leads to deconstructing, discrediting, and demonizing the opponent's political party image. Although Schuster's conclusions were full of dramatic statements and almost apocalyptic predictions, their reinterpretation was necessary. The application of $F$-test as a measure of testing statistical hypotheses relevant to empirical data, allowed to search for additional political and psychological explanatory models of the "emotional map of Ukraine". The results of the study demonstrate hidden suggestion of hopelessness, feelings of betrayal, protest moods inspired by the speakers invited to the TV show. This adversely affects the critical understanding of current social processes along with the radicalization of public sentiment by shifting the locus of control to the outside, when the audience invited to the show delegates responsibility for the state of affairs in the country and their well-being to their political leaders.
\end{abstract}

Keywords: narrative, media, individual behavior, conversational analysis, intent analysis, mass emotions.

\section{Карпенко Зіновія. Психометрика, риторика, наратив у контексті медіапсихо- лінгвістики}

Анотація. Статтю присвячено критичному дослідженню організації, представлення і тлумачення результатів тривалого експерименту в медіасередовищі. Результати експерименту відображено в опублікованій 2018 року книзі «Свобода слова проти страху і приниження», автором якої є український політичний журналіст та ведучий ток-шоу «Свобода слова» Савік Шустер. Метою дослідження є визначення чинників соціальної поведінки української аудиторії. Серед методів застосовано наративний, конверсаційний та інтент-аналіз конфліктної взаємодії учасників політичного ток-шоу. Ці інструменти дали змогу експлікувати провідні теми, смисли, рольові позиції, архетипні патерни поведінки учасників та ведучого. За матеріалами рефлексивного дискурсу самопрезентації автора книжки встановлено, що провідним видом описаних ним наративів $є$ деструктивно-

(C) Karpenko, Zinoviia, 2020.

This is an Open Access article distributed under the terms and conditions of the Creative Commons Attribution 4.0 International Licence (https://creativecommons.org/licenses/by/4.0/).

East European Journal of Psycholinguistics, 7(2),80-96. https://doi.org/10.29038/eejpl.2020.7.2.kar 
конфронтаційний, тематичне ядро якого становить інспірування непримиренного суспільного протистояння й делегітимізація державної влади. Наративна структура «негативних» сценаріїв ток-шоу, описана в книзі, дала змогу визначити ведучого як підбурювача конфліктної поведінки спікерів, високу напруженість їхнього дискурсу, що призводить до деконструкції, дискредитації та демонізації іміджу політичної партії опонента. Хоча висновки Шустера насичені драматичними висловлюваннями та майже апокаліптичними передбаченнями, необхідним $є$ їхнє критичне осмислення. Застосування $\varphi^{*}$-критерію Фішера як методу перевірки статистичних гіпотез дало змогу встановити додаткові політичні та психологічні пояснювальні моделі «емоційної карти України». Результати дослідження демонструють безнадійність, почуття зради, протестні настрої внаслідок сугестивного впливу з боку запрошених до телешоу спікерів. Це в свою чергу погіршує критичне осмислення актуальних суспільних процесів поряд із радикалізацією суспільних настроїв $з$ перемиканням локусу контролю назовні, коли запрошеним на шоу лідерам громадської думки глядачі делегують відповідальність за стан справ у державі та власне благополуччя.

Ключові слова: наратив, медіа, поведінка особистості, конверсаційний аналіз, інтент-аналіз, масові емочії.

\section{Introduction}

Individual social behavior is the object of numerous interdisciplinary studies. The search for objective-materialist (neurophysiological, economic) factors and mechanisms of this behavior is shifted towards the creation of cognitive-evaluative, interpretive models. Psycholinguistic studies of such phenomenological correlates of social behavior as emotions, feelings, traumatic experiences, have intensified of late. Scholars found a link between the intensity of emotions and the lexical modalities of their expression (Argaman, 2010). A new methodology for measuring negative bias using the positive and negative vocabulary of emotional words used in autobiographical stories has been applied (Cohen, 2011). Bartczak \& Bokus (2017) measured the semantic distance between the 'Self' and five conceptualized concepts of past, future, joy, sadness, and happiness. Gawda (2013) analyzed the emotional vocabulary and narratives of people with an antisocial personality disorder, while (Voyer \& Vu, 2016) determined the conditions of perception of sarcasm.

Moïsi (2010) in his theory of mass emotions attempted to link large-scale geopolitical transformations with dominant emotions typical of large communities was the theory of mass emotions. In Moïsi's opinion, mass emotions of fear and humiliation are a source of interethnic, racial, religious and ethnocultural hostility leading to destructive practices (terrorism, war, genocide). These emotions are actually markers of unrealized motivations of large communities and serve as predictors of social unrest (revolutions, wars, riots). The only emotion that can resist the outbreak of violence against a properly identified or misdiagnosed hostile group suffering and persecution is the emotion of hope, supported by liberaldemocratic legal norms and procedures, which gives a chance for a peaceful, constructive solution to pressing social problems and conflicts.

Moïsi believes that the modern globalized world is divided into three cultures - of fear (dominates in the United States and Western Europe), of humiliation 
(predominant in Muslim Arabic cultures), of hope (India, China, the countries of the East Pacific).

This theory inspired the famous Ukrainian journalist Shuster (2018) to test it empirically in Ukraine. In his book, the journalist tried to fill a vacant niche in Moïsi's proposed global map of emotions.

With this goal in mind, Shuster asked a question about the place of Ukraine on the global geopolitical map of emotions, since the fact of revolutionary, fateful events that took place and are taking place in Ukraine and other countries today is undeniable. It is worth paying tribute to the journalist's civic initiative and scientific interest that brought significant results: for the first time ever, a live socio-psychological experimental study has been held during a year and a half (from October 2015 to December 2016) embracing 46 talk shows "Shuster-Life". The study involved 4,600 people (100 people for each TV show lasting 4 hours). A team of sociologists ensured an even quota distribution of the TV show participants by their place of residence (region, city/village), age, and gender. As a result, a huge array of empirical data was collected, which has so far been only superficially statistically processed but has been hermeneutically elaborated in sufficient detail and insight. The research intuition of the author and TV show host enabled him to distinguish three emotional zones on the map of Ukraine: stability, borderline state, instability.

\section{Methods}

The article is the result of critical methodological reflection and a comparative, interdisciplinary approach to the interpretation of descriptive statistical characteristics. Among the main theoretical sources were works in media psychology (Winterhoff-Spurk, 2007; Hutsuliak, 2016; Naidonova, 2013; Petrunko, 2010; Vartanova, Zinchenko, \& Mironova, 2011), psycholinguistic aspects of media functioning (Kompantseva, 2018; Kosmeda, 2000; Mezhov, Navalna, \& Kostusiak, 2020), political psychology (Kaldor \& Vejvoda, 1999; Karpenko, 2015; Pocheptsov, 2015; Pavlova, Grebenshchikova, 2017).

The goal purpose of this study is 1) to check the statistical significance of the general indicators of the emotional well-being of Ukrainians and on this basis to clarify the factors and predictors of their social behavior. To do this, we used the percentage data published in Schuster's book (2018), placed in the relevant statistical tables (see tabs between pages 256 and 257); 2) to carry out a narrative analysis of Schuster's description of his experience of conducting political TV talk shows; 3) with the help of conversational analysis to illustrate the psycholinguistic features of the conflicting interaction of TV talk show participants; 4) apply intent analysis to identify the motivational and value orientation and dispositional characteristics of the narrator.

Next, I will focus on some important omissions in the analysis of the emotional state of the Ukraine citizens made by Schuster, due primarily to the insufficient level of statistical provability of his research results. It should be emphasized that the verification of the statistical significance of the percentages 
was taken from open sources, which allowed us to apply Fisher's angular transformation criterion $\varphi$, which is used to compare two samples by frequency of observed effects (Sidorenko, 1996, p. 157-171). The formulation of conclusions would be premature without careful verification of the differences of the samples with an empirically fixed answer to the host's (experimenter's) questions, as such conclusions could show bias, personal values, and subjective preferences of the researcher (Druzhinin, 2000).

Methodological triangulation (Flick, 1998; Johnson \& Onwuegbuzie, 2004; Terrell, 2012; Dvornik, 2013; Karpenko, 2017) was used to gain consistent psychological knowledge about the possibility of direct fixation of human emotional experience in the media environment, understanding, interpretation of the received artifacts during a public discussion on TV. A hermeneutic method in its variants, such as narrative analysis (Crossley, 2013; Kellett, 2010), partly conversational analysis (Ulanovsky, 2016), discourse analysis (Kalmykov, 2017) in their relation to conflict communication and information and psychological warfare (Balyasnikova, 2015; Pryschepa, 2017; Knyazeva, Tikhonova \& Kurbakov, 2019) are supplementary tools.

\section{Results and Discussion}

The book contains answers to the question: "With what emotion do you leave the studio: the emotion of fear of tomorrow, hope for tomorrow or humiliation because of the conditions in which you live?"

Verification of the statistical significance of differences in the indicators of the evaluation construct "hope" by Fisher's criterion $\varphi$ in the transgenerational dimension showed that there is a significant difference at 0.02 between the generation of millennials (18-29 years) and the active generation (30-44 years): the former are more optimistic than the latter (66\% vs. $62 \%)$. The active generation differs slightly from the mature $(45-59$ years $)(p=0.07)$; while "mature" participants are somewhat more optimistic than "active" ones (65\% vs. 62\%). Also, there is a statistically significant difference at the level of $0.02(65 \%$ vs. $61 \%$, respectively) between the mature and older (over 60 years) generations. A comparison of the youngest and most mature participants shows almost identical data $-66 \%$ and $65 \%$ respectively. The statistical inaccuracy of the differences in the optimistic attitude to the future of the generations 18-29 and 45-59 indicates the semantic similarity of these different age tasks of life. The similarity is observed between generations 30-44 and over 60 years $(62 \%$ and $61 \%$, respectively). Such results can be interpreted in the sense of alternation of ontogenetic rhythms when the onset of adulthood (millennials) and the maximum of self-realization (45-59 years) are marked by faith in good prospects for their lives. However, the age periods of 30-44 and over 60 are characterized by a critical assessment of the implemented plans and, possibly, a reduction in the level of demands due to limited personal resources (intellectual, educational, professional, material, and physical) to achieve goals. 
For obvious reasons, Schuster did not provide an ontogenetic explanation based on the transgenerational comparison of the experience of hope, but this explanation cannot be rejected. On the contrary, modern developmental psychology lacks works with large-scale comparisons of representative samples formed by age. A simple calculation shows that the sample of each generation was represented by 1,150 participants, since the whole sample was represented by 4,600 participants). Schuster was more interested in the political and psychological motives of this state of affairs. He draws a disappointing conclusion about the lack of hope among Ukrainians, who need to demonstrate a result of at least $75 \%$ to achieve optimal viability (Shuster, 2018, p. 277-278). His ideal distribution of mass emotions was as follows: hope $-76 \%$, humiliation, and fear $-12 \%$ each, while actual indicators the Ukrainian participants showed were as follows: hope $-63.7 \%$, humiliation $18.8 \%$, fear $-17.5 \%$ (Shuster, 2018, p. 277-278). The researcher bases his conclusions on his personal life experience, intuition, own firm belief in the ideality of such a phenomenological standard for effective progressive changes in society.

However, a strict approach to the research procedure reveals a number of errors that cause incorrect conclusions made by Schuster. A fundamental error is the semantic polarization of emotions as phenomena of reflected experience. From this standpoint, the emotion of hope opposes the emotions of fear and humiliation as both sthenic (evoking activity) and asthenic (blocking energy) poles of a single personal construct of self-experience in the world. Thus, the participants of the TV show actually had to make not a one-time choice, but a choice that consisted of two steps: 1) choosing the positive (wall, optimistic) or negative (asthenic, pessimistic) pole of the personal construct of attitude to life/experience of life; 2) determining the modality of the negative pole - fear or humiliation if the negative pole of this semantic opposition was chosen. Fear symbolizes a protective motivational tendency (fear of failure, fear of "not being even worse!"). Humiliation is associated with self-suppression and compulsive accumulation of envy and anger at subjects unfavorable for a particular person (community) comparisons of achievements, skills, competencies, power. From these considerations it follows that the theoretical probability of choosing hope is one chance out of two, i.e. $50 \%$; a similar probability of choosing fear or humiliation is one chance out of four, i.e. $25 \%$, and not $33.3 \%$ if the choice was made once. In fact, the obtained indicators of diagnosed emotions are significantly higher as for hope and lower as for fear and humiliation.

Below are percentages for both negative emotions (Schuster considered them as independent characteristics) among the participants: millennials - 34\% (20\% fear and $14 \%$ humiliation), active generation - 38\% (19\% of both emotions), mature generation $-35 \%$ (16\% and $19 \%$ respectively), older generation $-38 \%$ (15\% fear and $23 \%$ humiliation). The result of checking the significance of intergenerational differences in the recorded indicators of the negative emotional spectrum and pessimistic life orientation reproduces the rhythmic fluctuations of the emotional state of hope, only in a complementary (mirror) reflection. Thus, millennials differ significantly $(\mathrm{p}=0.02)$ from the active generation, whose mode 
of life contains more protective and depressive features. No significant differences in the negative pole of emotional well-being $(\mathrm{p}=0.06)$, but significant subsystemic differences at the level of 0.03 , achieved by reducing fear in adulthood, are found out between the active and mature. No differences between the mature and older generations, but the redistribution of negative emotions is increasing with older people fearing less but feeling more humiliation (these emotions' polarization is significant at $\mathrm{p}=0.00$ ). This result is more than convincing: fear of the future fades their helplessness, lack of subjectivity, physical and material ability to change the course of events, to improve their living conditions.

As we see, the reinterpretation of the results obtained by Schuster became possible due to applying the method of testing statistical hypotheses relevant to empirical data, namely Fisher's criterion $\varphi$, which allowed searching for additional political and psychological explanatory models of "emotional map of Ukraine" while avoiding radical one-sided conclusions, disappointing forecasts. Instead, Schuster's conclusions are full of dramatic statements and apocalyptic predictions.

Although Moïsi in his theory uses no traditional socio-psychological methods, like surveys, expert assessments, experiments, and quantitative analysis of empirical data, he substantiates his theory not nomothetically, but ideographically by considering unique representative cases, and not with the involvement of representative samples. Moïsi's extensive political discourse analysis serves to accumulate historical analogies and phenomenological reduction as a specific hermeneutic procedure "dries up" recurring events, behavioral patterns of human communities, elites, and leaders to their most essential intentional and emotional core of social and political transformations. It should be noted that Moïsi nowhere violates the "purity of the genre", i.e. does not apply mixed methodology, or use methodological triangulation in understanding the complementarity of hermeneutic-interpretive and experimental-statistical strategies for building his theory of mass emotions. In this respect, the attempts of Shuster to apply methodological triangulation to the construction of a holistic descriptiveexplanatory-prognostic model of mass emotions of Ukrainian citizens cannot be considered successful due to certain shortcomings in determining the statistical norm of mental development and individual health (Morgun \& Titov, 2009, p. 7576). Schuster supports rather a socio-psychological norm, advocating for the desired, ideal order of things (as he understands it). However, he uses for this purpose superficial and not very carefully worked out diagnostic and statistical procedures, which ultimately lead him to arbitrary, biased conclusions and utopian recommendations. Among them is the immediate introduction in Ukraine of unconditional basic income (Shuster, 2018, p. 280-282) guaranteed to all citizens of the country regardless of whether they work (worked) or not, whether they are sick or healthy, children or adults.

The shortcomings of the psychometrics of mass emotions analyzed above, which led to speculative conclusions, are not the only problem that causes insufficient validity and representativeness of the experimental study. The narrative structure of the talk show, which is formed by several important topics for 
discussion by authoritative speakers associated with the most resonant events that took place in a certain period, also leads to biased conclusions in the form of the Pygmalion effect and their large-scale manipulative influence on public consciousness (Barnum effect). The host (and simultaneously observer-researcher, interpreter, narrator, and transmitter of subjective "truth") is responsible for talk show drama: selecting and sequencing of topics and events, inviting speakers as voices of different ideological trends, regulating the order of giving a floor to speak or comment, demonstrating videos that provide an associative order of meanings in the case of "historical" truth (presentation of objective facts) or metaphorical synchronized meanings that symbolize a social problem and contain an archetypal code of its predominant solution in a certain society (the so-called narrative truth). As a result of the active involvement of the host as a narrator, the talk show participants construct a usually negative conflict narrative that not only reflects the value positions of the participants, but also helps their public "crystallization", the polarization of vision, evaluation, and approaches to solving problems. This actualizes the chain of opposition to the rhetorical transactions of political opponents, whose ultimate goal is to struggle for power by imposing one's narrative on the recipients of media products and gaining the widest possible circle of supporters. According to Kellett, the plots of almost all conflict narratives play on competitive themes of power and domination, personal independent influence, on the one hand, and pertaining, adaptation, attachment to a group and traditions, on the other hand (Kellett, 2010). It is this axiological dilemma that serves as a universal driving force of social discourses and narratives, from individual lifecreation to global civilizational transformations.

Schuster's book contains 7 examples of narratives consisting of a description, author's commentary, and a more or less detailed interpretation of the discussion of current issues with their extrapolation to public sentiment, which was recorded at the beginning and end of the talk show. Significantly, only one of the seven narratives selected for the case study had an optimistic finale (increased hope and reduced fear and humiliation), while the other six reflected the above-mentioned trend of growing insecurity and humiliation while despairing of "bright prospects."

The narrative structure of "negative" scenarios of the talk show described in the book enabled defining the host as the encourager of the speakers' conflict behavior, high tension of their discourse that leads to deconstructing, discrediting, and demonizing the opponent's political party image. The purpose of such a narrative is to discredit the enemy by one-sided and distorted coverage of his activities and delegating to him the exclusive responsibility for the state of affairs in the country. The "enemy" in the narrative is endowed with such negative features as "corrupt", "thief", "thug", "bandit", "oligarch" - a semantic syncret of greed, monopoly position in business, the power to influence media content, to bribe deputies for promoting their business interests. The typical discourse of opponents is formed by the accusations of predecessors, which, on one hand, establishes a conflicting narrative in the past, and on the other - deprives the alternative narrative of reconstructive, life-giving force, since the condition of its 
constructiveness is the historical longevity dialogue, finding opportunities for cooperation with the inevitable concessions to each other. Nurturing value-oriented unity of citizens (with respect for them as the antithesis of humiliation and a sense of existential security that awakens initiative being the antithesis of fear) on the crucial issues of state-building and strengthening the economic foundations of life will be able to combine two motivational tendencies. They are a drive for power (control) as isolated from the plebs domination and a drive for acceptance/love as involvement in the group, commitment to people in a solid dialectical core of future social change.

Taken together, it is worth rethinking both the narrative role and the rhetorical function of the talk show host, which is to move from a purely psychoanalytic position of an attentive but detached, "neutral" listener to a facilitator position. In the first position, the host uses appropriate conversational moves to emphasize the contradictions in the participants' discourses, encouraging them to express their idealized projections in the form of selfless pursuit of the public good and the role of advocate of justice in their political power. The confrontation of the participants intensified in this way, which sometimes reaches the heights of theatrical action, is stopped by the format of the show in the genre of satire. It is worth recalling here that White singled out four basic emplotments provided by the archetypical genres of romance, comedy, tragedy, and satire (Crossley, 2013, p. 84). Satire does not recognize interdependence and shared empathic responsibility, because it is a work of exposing character. "The object of satire is the antipodes of universal morality; hyperbolization and grotesque are widely used here (Gromyak \& Kovaliv, 1997, p. 624-625). For example, the escalation of confrontational tensions between "the righteous" and "the criminal" has led to the following fact:

"Oles Donii, a member of the Verkhovna Rada, an "educated nationalist", one of the active participants in the student actions of the struggle for independence in the late 1980s - early 1990s, went on a provocation:

- The one who shoots Yanukovych and Zakharchenko will perform an act of humanity. $74 \%$ of the audience support this and applaud", (Shuster, 2018, p. 82).

The extrapolation of "satirical" programming has grown into its critical manifestation of life, which served as a turning point in the development of the real confrontation on the Maidan in February 2014:

"One of the centurions, 26-year-old Volodymyr Parasyuk, broke into the microphone on the stage and presented an ultimatum:

- No Yanukovych will rule for another year! He has to leave by ten o'clock tomorrow! If by ten o'clock in the morning our politicians do not make a statement that Yanukovych should resign immediately - you hear, immediately! - then we go on the assault with weapons! I swear to you!

\footnotetext{
${ }^{1}$ All translations are made by the author of this article.
} 
The Maidan supported the centurion in tears and excitement" (Shuster, 2018, p. 81-82).

Realizing his personal responsibility for the limited programming of talk shows and the materialization of a possible future, Shuster is filled with remorse:

"I still can't get rid of the feeling that contributed to the emergence of Parasyuk's ultimatum. The program was watched at 7:30 p.m., it was watched on the Maidan. At 20:22 my question about Yanukovych's voluntary resignation sounded, and at 20:30 Parasyuk moved onto the stage: either resignation or lynching!” (Schuster, 2018, p. 83).

Here is another reflection that shows the synchronicity and reciprocity of transitions between media, virtual, and real fact:

"In order for a political talk show to immediately attract viewers, an overture or an acute conflict is needed in the overture, the initial part of the program. But on this day the most important thing was to learn the information first hand. I decided to give the first word to Pavel Sheremet, my old acquaintance, a friend of Boris Nemtsov. A year after this program, Boris was first shot next to the Kremlin, and two years later Pavlo was blown up with a small one in the center of Kyiv"(Shuster, 2018, p. 80).

It is important to note that the semantic center of Schuster's book is the discourse of the journalist's self-presentation as the author of a reflective description of the events that took place on his talk show. The personality of the host as a reference object of outward and inward intentions plays a mediating role in the discussion of current issues that have been the subject of discussions on television.

Intent analysis of self-presenting rhetorical figures used by Schuster indicates the emphasis on its public significance and influence:

"Perhaps it was not worth leaving Kyiv and thus tempting Yanukovych's loyal hawks, who wanted to get rid of me at any cost!'”(Schuster, 2018, p. 60).

The following excerpt of the conversation shows the reliability of his expert judgment:

"There will be blood, and we in Europe will have enough," I told Peter.

"You're exaggerating," he replied, like a typical British journalist who sticks to the facts, not intuition" (Schuster, 2018, p. 72).

Thus, the author of the book claims the superiority of his prediction as a more reliable over the forecast of a typical representative of the Western media. An 
excerpt from another conversation in the book aims to convince the reader of the author's geopolitical insight, again by contrasting a single argument, in the irrefutable provability of which the journalist has no doubt, the interlocutor's weak attempt to deny him:

"You'll see, they will take Crimea, and the war will begin," I understood that the law of the first murder had already come into force and the fate of Crimea had already been decided.

"No, there may be casualties, but there will be no war," my friend said firmly.

We met again four months later, he was on his way to war in the Donbass" (Shuster, 2018, p. 77).

A strong subconscious desire for comprehensive control is evidenced by the following nostalgic memory of Schuster, who quotes his friend about the "strategic" location of his apartment in Florence:

"If you put a machine gun here, you'll be able to control the whole block!" (Schuster, 2018, p. 61).

His courage manifestation is aimed at awakening readers' faith in the selfless subordination of their professional activities to the social mission of journalism, based on the ideas of freedom, justice, and humanism:

"... If you are afraid of the wrath of presidents, you should not be a journalist” (Shuster, 2018, p. 94).

Shuster's personal self-affirmation through his subjectivity, feeling of power and control, is conveyed in the following experience:

"For me, the studio is the most comfortable place in the world. Actually, the studio is my world. But I spent a few hours in the strongest tension: you keep in mind the reaction of the audience and the guests' remarks, so as not to miss important accents, filter the information from the editor on the "ear", follow the news coming during the program, and combine all these parties into a single drama show" (Shuster, 2018, p. 104).

Unsurprisingly, the intention of one's competence, influence, and subjective grandeur leads to the fact that only POWER as a collective image of institutional power and administrative resource turns out to be worthy (not in the ethical sense of the word), actually, a moderate rival of an individual (here - unique), whose vision unites the claims of a huge number of oppressed, robbed, deceived citizens.

It should be noted that Shuster rarely uses direct invectives (Mezhov et al., 2020) aimed at his ideological opponents in the live course of the show; exposure of "criminal power" is carried out indirectly, through the selection of topics, stories, 
speakers, whose role in the show is determined by the clan-oligarchic interests of representatives of various political forces invited to participate in the show. However, the intention of rejection and disgust for the "usurper of the people's hope" - the then incumbent President Poroshenko was conveyed through the depiction, for example, of the following household details:

"I was taken to a guest room on the president's sixth floor. Unlike the modest office where Poroshenko and I met in the spring, there was an expensive distaste: a chandelier overloaded with crystal curls hung over the gilded furniture. The wallpaper was pressed with its bulky ornament" (Shuster, 2018, p. 121).

After such a massive self-presentation and depiction of the confrontation with the already post-Maidan authorities, the author of the book allows himself a cunning confession:

() "I do not overestimate the importance of my person. I haven't needed to prove my courage or anything to anyone for a long time. But it so happened that many people know me personally, and my murder would be loud news in Ukraine. It was in the interests of the authorities to ensure the safety of our film crew" (Shuster, 2018, p. 124).

Imitation of modesty is an attempt to conform to the socially acceptable pattern of a simple Hero, loved by the people and chosen by them, fighter against Evil. Thus, the second half of the book is full of the author's intentions of selfconfidence, which is supported by an appeal to the arguments concerning objective things, a balanced analysis of situations. Schuster's discourse becomes less emotionally charged, but the appeal to statistical analysis was still unsuccessful, despite the author's belief in his scientific knowledge, which led him to speculative conclusions (which I drew attention to above).

The increase in initiatives, recommendations, and appeals addressed primarily to the generation of 30-44-year-olds eventually led Schuster to a populist project of unconditional basic income:

"Basic income is a form of social protection that provides each citizen of the country with the amount of money needed for normal daily life. Such money is paid by the political community (in the case of Ukraine - the state, region, or city) to each of its members, regardless of what he owns and whether he works or not”. (Shuster, 2018, p. 281).

In his substantiating his own "plan for the survival of Ukraine", Shuster resorted to some economic calculations, which obviously have the same "scientific validity" as speculative conclusions made based on a totally subjective assessment of the emotions of talk show participants. The lack of response from authoritative 
experts in the field of economics indicates that the declaration of Schuster in the arrangement of public life does not deserve serious attention.

How does a narrative with an optimistic ending differ from a narrative of the type described above? The answer is found in an excerpt from the book with the eloquent Chapter "Babyn Yar. Hope Is Born in Tragedy" (Shuster, 2018, p. 247256). With a strong reliance on historical facts and the presence of living witnesses to the distant events of September 1941, the host's confrontation as a rhetorical figure is transformed into a convincing argument aimed at entering the hermeneutic circle of common discourse: acceptance of responsibility - awareness of guilt repentance and forgiveness. Shuster states:

"When I saw that after such a difficult, painful, and acute topic, the audience's hope increased by $25 \%$, I was once again convinced that the most important thing for the people is to know the truth. When they are honest with him, then they respect him. Then he is ready to hear and take responsibility for his past, present, and future" (Shuster, 2018, p. 255-256).

The effect of catharsis came at the end of the talk show. It symbolized the huge illocutionary potential of this dialogically directed by the host as a facilitator of conflict discourse tolerant respect and joint efforts for a better future free from racial, ethnic, and national prejudices including anti-Semitism, various forms of hatred, enmity, and revenge. Here the intentions and discursive actions of the participants were balanced and symmetrical.

\section{Conclusions}

The conceptual and methodological flaws described in this article do not in any way underrate Moïsi and his follower Shuster's contribution to the study of the driving forces of social transformations in the modern globalized world. Instead, we should speak about the urgency of complex, interdisciplinary studies of the raised problem. This needs a combination of qualitative (hermeneutic and phenomenological, existential, conversational, intentional analyses) and quantitative (observational-experimental-psychodiagnostic methods with application of statistical procedures) tools of studying emotions as drivers and predictors of social behavior of individuals and communities.

Comparative research using a set of tools to study emotional motivators of social behavior of different state institutions, regional communities, ethnocultural enclaves, etc. would be useful. The procedure for selecting and approving the list of questions for participants of political talk shows should be improved. For example, the final tables included self-assessments of emotions experienced at the end of the show, which were usually more pessimistic than at the beginning of the show. This could be the result of the hidden suggestion of hopelessness, feelings of betrayal, protest moods inspired by the invited speakers. Similarly, this could be a consequence of planning the show by the host and editorial board, in which the 
quantitative balance of opposing views increases intellectual tension and constructs a field of conflicting personal meanings of program participants and its viewers.

This adversely affects the critical understanding of current social processes along with the radicalization of public sentiment by shifting the locus of control to the outside, when the audience invited to the show delegates responsibility for the state of affairs in the country and their well-being to their political leaders. It follows that the effective direction of the show, which provides a high and stable rating of the program, must be complemented by effective sociotherapy (Kellet, 2010), which would ensure productive facilitation of social dialogue, achieving value-oriented unity of citizens on key issues of statehood and solidarity. the state of affairs in the state and the immediate social environment.

It would be possible not to impose such strict requirements on the journalistic publication of even a famous journalist, if not for its wide advertising, ubiquitous presence in bookstores (circulation of the book for some reason is not specified), and, most importantly, the remarkable ambitions of the author, expressed literally in the first sentence of the book abstract: "In his authorial debut, Savik Shuster builds the emotional map of Ukraine" (Schuster, 2018, p. 2). Given the renewal of the journalist's author's program today and the numerous examples of the shortcomings of quantitative and qualitative analysis of the collected empirical data discovered here, the socio-psychological expert environment, the Association of Political Psychologists of Ukraine, the domestic media community should unite their efforts to establish dialogue and correct coverage of the results of such "live social experiments".

This research has thrown up many questions in need of further investigation of the author's principle of integral subjectivity, most fully presented in the second edition of the monograph Axiological Psychology of Personality (Karpenko, 2018) and its contribution to the realm of mass emotions. Further research might test the hypothesis of the hierarchical representation of the considered key emotions and their semantic antipodes regarding the presence of a human in different natural and socio-cultural contexts of existence and in their temporal landmarks.

\section{References}

Балясникова О. В. Возможности и перспективы этнопсихолингвистического исследования конфликта. Вопросы психолингвистики. 2015. Вып. 4, № 26. С. 12-20.

Гуцуляк О. Філософія української сутності: соціокультурні смисли алхімії національного буття. Київ: Арт Економі, 2016. 256 с.

Дворник М. Змішана методологія досліджень соціально-психологічних практик. Психологія особистості. 2013. Вип. 1, № 4. С. 95-103.

Дружинин В. Н. Экспериментальная психология. Санкт-Петербург: Издательство «Питер», 2000. $320 \mathrm{c}$.

Калмиков Г. Професійно-психологічний дискурс як інструмент впливу на адресата. $\begin{array}{llllll}\text { Psycholinguistics. } 2017 . & \text { Вип. 22, № } & 1 . & \text { C.112-127. }\end{array}$ https://doi.org/10.5281/zenodo.1087770

Карпенко 3. С. Психолого-історична реконструкція соціальних міфологем як метод протидії маніпулятивним медіатехнологіям. Проблеми політичної психологї. 2015. Вип. 2. С. 361-370. 
Карпенко 3. Епістемологічні модуси методологічної тріангуляції в персонології. Психологія особистості. 2017. Вип. 1, № 8. С. 7-13.

Карпенко 3. Аксіологічна психологія особистості: монографія. 2-ге вид., перероб., доповн. Івано-Франківськ: ДВНЗ «Прикарпатський національний університет імені Василя Стефаника», $2018.720 \mathrm{c}$.

Князева Е. Г., Тихонова Е. В., Курбаков И. А. Психолингвистическое исследование конфликтогенных языковых единиц в медийном дискурсе. Bonpocbl психолингвистики. 2019. Вып. 1, № 39. С. 102-117. https://doi.org/10.30982/2077-59112019-39-1-102-117

Компанцева Л. Психолінгвістичний опис нових медіа. Psycholinguistics. 2018. Bun. 23(2). C. 120-131. https://doi.org/10.5281/zenodo.1208639

Космеда Т. Аксіологічні аспекти прагмалінгвістики: формування і розвиток категорії оцінки. Львів : ЛНУ ім. Івана Франка, 2000. 350 с.

Літературознавчий словник-довідник / Р. Т. Гром'як, Ю. І. Ковалів та ін. Київ : ВЦ «Академія», 1997. 752 с.

Моргун В. Ф., Тітов І. Г. Основи психологічної діагностики: Навчальний посібник для студентів вищих навчальних закладів. Київ: Видавничий Дім «Слово», 2009. 464 с.

Найдьонова Л. А. Медіапсихологія: основи рефлексивного підходу: підручник. Кіровоград: Імекс-ЛТД, 2013. 244 с.

Павлова Н. Д., Гребенщикова Т. А. Интент-анализ постсобытийного дискурса в интернете. Психологические исследования, 2017, Bыn. 10. № 52. URL: http://psystudy.ru

Петрунько О. В. Діти і медіа: соціалізація в агресивному медіасередовищі: Монографія. Полтава : ТОВ НВП «Укрпромторгсервіс», 2010. 480 с.

Почепцов Г. Сучасні інформаційні війни. Київ: Вид. дім «Києво-Могилянська академія», 2015. $497 \mathrm{c}$.

Прищепа Г. «Мова ненависті» як лінгвістичний маркер «гібридної війни». Psycholinguistics. 2017. Вип. 22, № 2. С. 98-112. https://doi.org/10.5281/zenodo.1069546

Сидоренко Е. В. Методы математической обработки в психологии. Санкт-Петербург : Социально-психологический Центр, 1996. 332 с.

Улановский А. М. Феноменология разговора: метод конверсационного анализа. Вопросы психолингвистики. 2016. Вып. 1, № 27. С. 218-237.

Человек как субъект и объект медиапсихологии / под ред. Е. Л. Вартанова; Ю. П. Зинченко, В. В. Миронова. Москва: МГУ имени М. В. Ломоносова / Ин-т человека; Изд-во Моск. ун-та, 2011. 824 с.

Argaman, O. (2010). Linguistic markers and emotional intensity. Journal of Psycholinguistic Research, 39, 89-99. https://doi.org/10.1007/s10936-009-9127-1

Bartczak, M., Bokus, B. (2017). Semantic distances in depression: relations between ME and PAST, FUTURE, JOY, SADNESS, HAPPINESS. Journal of Psycholinguistic Research, 46, 345-366. https://doi.org/10.1007/s10936-016-9442-2

Cohen, S. J. (2011). Measurement of negativity bias in personal narratives using corpus-based emotion dictionaries. Journal of Psycholinguistic Research, 40, 119-135 https://doi.org/10.1007/s10936-010-9158-7

Crossley, M. L. (2000). Introducing Narrative Psychology: Self, Trauma and the Construction of Meaning. Open University Press.

Flick, U. (1998). An Introduction to Qualitative Research. Thousand Oaks: Sage.

Gawda, B. (2013). The emotional lexicon of individuals diagnosed with antisocial personality disorder. Journal of Psycholinguistic Research, 42, 571-580. https://doi.org/10.1007/s10936-012-9237-z

Hofstede, G. (1998). Masculinity and Femininity: The Taboo Dimension of National Cultures. Thousand Oaks: Sage. 
Imbir, K. K. (2017). Valence and origin of emotional words influence on subsequent perception of ambiguous stimuli in terms of competence versus warmth. Journal of Psycholinguistic Research, 46, 1549-1571. https://doi.org/10.1007/s10936-017-9505-Z

Johnson, B., Onwuegbuzie, A. (2004). Mixed methods research: A research paradigm whose time has come. Educational Researcher, 7, 21-22.

Kaldor M., Vejvoda, I. (Eds.) (1999). Democratization in Central and Eastern Europe. London, New York.

Karpenko Z. (2015). Axiopsychological refutation of totalitarian ideologisms in the era of globalization. Annales Universitats Mariae Curie-Sklodowska, 28(2), 59-70. https://doi.org/10.17951/j.2015.28.2.59

Kellett, P. (2007). Conflict Dialogue: Working with Layers of Meaning for Productive Relationships. Thousand Oaks, CA: SAGE Publications, Inc. https://www.doi.org/10.4135/9781452225852

Mezhov, O., Navalna, M., \& Kostusiak, N. (2020). Invective vocabulary in media discourse at the beginning of the 21st century: A psycholinguistic aspect. East European Journal of Psycholinguistics, 7(1), 97-110. https://doi.org/10.29038/eejpl.2020.7.1.mez

Moïsi, D. (2010). The Geopolitics of Emotion: How Cultures of Fear, Humiliation, and Hope are Reshaping the World. New York: Anchor Books.

Terrell, S. R. (2012). Mixed-methods research methodologies. The Qualitative Report, 17(1), 254-280. Retrieved from https://nsuworks.nova.edu/tqr/vol17/iss1/14

Voyer, D. \& Vu, J. P. (2016). Using sarcasm to compliment: Context, intonation, and the perception of statements with a negative literal meaning. Journal of Psycholinguistic Research, 45, 615-624. https://doi.org/10.1007/s10936-015-9363-5

Winterhoff-Spurk, P. (2003). Medienpsychologie. Eine Einfuhrung. Berlin: Kohlhammer.

\section{Джерело}

Шустер С. Свобода слова против страха и унижения. Социальный эксперимент в прямом эфире и первая карта эмоций Украины. Киев: Брайт Стар Паблишинг, 2018. 304 с.

\section{References (translated and transliterated)}

Balyasnikova, O. V. (2015). Vozmozhnosti i perspektivy etnopsikholingvisticheskogo issledovaniya konflikta [Opportunities and prospects of ethnopsycholinguistic research into conflict]. Journal of Psycholinguistics, 4(26), 12-20.

Hutsuliak, O. (2016). Filosofiia ukrainskoi sutnosti: sotsiokulturni smysly alkhimii natsionalnoho buttia [Philosophy of Ukrainian essence: socio-cultural meanings of alchemy of national existence]. Kyiv: Art.

Dvornyk, M. (2013). Zmishana metodolohiia doslidzhen sotsialno-psykholohichnykh praktyk [A mixed methodology research of social and psychological practices]. Psykholohiia Osobystosti - Psychology of Personality, 1(4), 95-103.

Druzhynin, V. N. (2000). Eksperimentalnaya Psikhologiya [Experimental Psychology]. S.Petersburg: Piter.

Kalmykov, H. Profesiyno-psykholohichnyi dyskurs yak instrument vplyvu na adresata [Professional and psychological discourse as an instrument of influence on the addressee]. Psycholinguistics, 22(1), 112-127 https://doi.org/10.5281/zenodo.1087770

Karpenko, Z. (2017). Epistemolohichni modusy metodolohichnoi trianhuliatsii v personolohii [Epistemological Modes of methodological triangulation in personology]. Psykholohiia Osobystosti - Psychology of Personality, 1(8), 7-13.

Karpenko, Z. (2018). Aksiolohichna psykholohiia osobystosti [Axiological psychology of personality]. 2nd ed. Ivano-Frankivsk: Vasyl Stefanyk Pre-Carpathian National University.

Karpenko, Z. (2015). Psykholoho-istorychna rekonstruktsiia sotsialnykh mifolohem yak metod protydii manipuliatyvnym mediatekhnolohiiam [Psychological and historical reconstruction 
of social mythologies as a method of counteracting manipulative mediatechnologies]. Problemy Politychnoyi Psykholohii - Problems of Political Psychology, 2, 361-370.

Knyazeva, E. G., Tikhonova, E. V., Kurbakov, I. A. (2019). Psikholingvisticheskoye issledovaniye konfliktogennykh yazykovykh edinits $\mathrm{v}$ mediynom diskurse [A psycholinguistic research into conflict-generating verbal means in modern media discourse]. Journal of Psycholinguistics, 1(39), 102-117. https://doi.org/10.30982/20775911-2019-39-1-102-117

Kompantseva, L. (2018). Psykholinhvistychnyi opys novykh media [Psycholinguistic description of new media]. Psycholinguistics, 23(2), 120-131. https://doi.org/10.5281/zenodo.1208639

Kosmeda, T. (2000). Aksiolohichni aspekty prahmalinhvistyky: formuvannia i rozvytok katehorii otsinky [Axiological aspects of pragmalinguistics: Formation and development of the evaluation category]. Lviv: Ivan Franko National University of Lviv.

Morhun, V. F., Titov, I. H. (2009). Osnovy psykholohichnoi diahnostyky [Fundamentals of psychological diagnosis]. Kyiv: Slovo.

Naidonova, L. A. (2013). Mediapsykholohiia: osnovy refleksyvnoho pidkhodu [Media psychology: basics of the reflexive approach]. Kirovohrad: Imeks-LTD.

Pavlova, N. D., Grebenshchikova, T. A. (2017). Intent-analiz postsobytiynogo diskursa v internete. [Intent analysis of post-event discourse on the Internet]. Psikhologicheskiye Issledovaniya - Psychological Research, 10(52). Retrieved from: http://psystudy.ru

Petrunko, O. V. (2010). Dity i media: sotsializatsiia v ahresyvnomu mediaseredovyshchi [Children and Media: Socialization in an Aggressive Media Environment]. Poltava: Ukrpromtorhservis.

Pocheptsov, H. (2015). Suchasni Informatsiini Viiny [Modern Information Wars]. Kyiv: KyivMohyla Academy.

Pryshchepa, H. (2017). "Mova nenavysti" yak linhvistychnyi marker "hibrydnoi viiny" ["Hate speech" as a linguistic marker of "hybrid war"]. Psycholinguistics, 22(2), 98-112. https://doi.org/10.5281/zenodo.1069546

Sydorenko, E. V. (1996). Metody matematycheskoy obrabotki v psykhologii [Methods of mathematical processing in psychology]. S.-Petersburg: Sotsyalno-Psikholohycheskiy Tsentr.

Ulanovsky, A. M. (2016). Fenomenologiya razgovora: metod konversatsionnogo analiza [Phenomenology of conversation: a method of conversion analysis.] Journal of Psycholinguistics, 27, 218-237.

Vartanova, E. L, Zynchenko, Yu. P., Myronova, V. V. (Eds.) (2011). Chelovek kak subyekt i obyekt mediapsikhologii [Human as a Subject and Object of Media Psychology]. Moscow: Moscow State University.

Argaman, O. (2010). Linguistic markers and emotional intensity. Journal of Psycholinguistic Research, 39, 89-99. https://doi.org/10.1007/s10936-009-9127-1

Bartczak, M., Bokus, B. (2017). Semantic distances in depression: relations between ME and PAST, FUTURE, JOY, SADNESS, HAPPINESS. Journal of Psycholinguistic Research, 46, 345-366. https://doi.org/10.1007/s10936-016-9442-2

Cohen, S. J. (2011). Measurement of negativity bias in personal narratives using corpus-based emotion dictionaries. Journal of Psycholinguistic Research, 40, 119-135 https://doi.org/10.1007/s10936-010-9158-7

Crossley, M. L. (2000). Introducing Narrative Psychology: Self, Trauma and the Construction of Meaning. Open University Press.

Flick, U. (1998). An Introduction to Qualitative Research. Thousand Oaks: Sage.

Gawda, B. (2013). The emotional lexicon of individuals diagnosed with antisocial personality disorder. Journal of Psycholinguistic Research, 42, 571-580. https://doi.org/10.1007/s10936-012-9237-z 
Hofstede, G. (1998). Masculinity and Femininity: The Taboo Dimension of National Cultures. Thousand Oaks: Sage.

Imbir, K. K. (2017). Valence and origin of emotional words influence on subsequent perception of ambiguous stimuli in terms of competence versus warmth. Journal of Psycholinguistic Research, 46, 1549-1571. https://doi.org/10.1007/s10936-017-9505-Z

Johnson, B., Onwuegbuzie, A. (2004). Mixed methods research: A research paradigm whose time has come. Educational Researcher, 7, 21-22.

Kaldor M., Vejvoda, I. (Eds.) (1999). Democratization in Central and Eastern Europe. London, New York.

Karpenko, Z. (2015). Axiopsychological refutation of totalitarian ideologisms in the era of globalization. Annales Universitats Mariae Curie-Sklodowska, 28(2), 59-70. https://doi.org/10.17951/j.2015.28.2.59

Kellett, P. (2007). Conflict Dialogue: Working with Layers of Meaning for Productive Relationships. Thousand Oaks, CA: SAGE Publications, Inc. https://www.doi.org/10.4135/9781452225852

Mezhov, O., Navalna, M., \& Kostusiak, N. (2020). Invective vocabulary in media discourse at the beginning of the 21st century: A psycholinguistic aspect. East European Journal of Psycholinguistics, 7(1), 97-110. https://doi.org/10.29038/eejpl.2020.7.1.mez

Moïsi, D. (2010). The Geopolitics of Emotion: How Cultures of Fear, Humiliation, and Hope are Reshaping the World. New York: Anchor Books.

Terrell, S. R. (2012). Mixed-methods research methodologies. The Qualitative Report, 17(1), 254-280. Retrieved from https://nsuworks.nova.edu/tqr/vol17/iss1/14

Voyer, D. \& Vu, J. P. (2016). Using sarcasm to compliment: Context, intonation, and the perception of statements with a negative literal meaning. Journal of Psycholinguistic Research, 45, 615-624. https://doi.org/10.1007/s10936-015-9363-5

Winterhoff-Spurk, P. (2003). Medienpsychologie. Eine Einfuhrung. Berlin: Kohlhammer.

\section{Source}

Shuster, S. (2018). Svoboda Slova Protiv Strakha i Unizhenia. Sotsyalnyi Eksperiment v Priamom Efire i Pervaia Karta Emotsyi Ukrainy [Freedom of Speech Against Fear and Humiliation. Social Experiment and the First Map of Ukraine's Emotions]. Kyiv: Bright Star Publishing. 